\title{
The role of terrestrial bromeliads in determining the spatial organization of plant life forms in a tropical coastal forest
}

\author{
Celio M. Lopes', Flora Misaki', Karina Santos², Carlos A. P. Evangelista ${ }^{3}$, Tatiana T. Carrijo² and Mário L. Garbin ${ }^{1 *}$
}

Received: December 13, 2016

Accepted: January 23, 2017

\begin{abstract}
The interplay between plant-plant interactions and light heterogeneity in the understory of tropical forests has rarely been examined. We aimed to identify the relative importance of the understory light environment and terrestrial bromeliads in explaining the abundance and spatial organization of different plant life forms along a coastal forest gradient from seashore inland in southeastern Brazil. We estimated the abundance of various life forms (herbs, woody plants, bromeliads, climbers, and palms) and the degree of light availability using hemispherical photographs in 165 plots $\left(1 \mathrm{~m}^{2}\right)$ within a 1.75 ha site. We used ordination methods, partial redundancy analysis (pRDA), spatial filtering using Moran's eigenvector mapping, and Moran's I splines. Forest cover was highly heterogeneous, but did not explain variation in abundance of life forms. Spatially, bromeliads were negatively associated with woody saplings, herbs and climbing plants at scales between 5-20 m, while the distance to seashore was found to be unrelated to these patterns. Our findings revealed that terrestrial bromeliads play an important role in the spatial organization of various life forms near the forest floor. Overall, the presence of terrestrial bromeliads and the plant area index better explained the understory vegetation than forest cover and distance to seashore.
\end{abstract}

Keywords: community assembly, hemispherical photographs, herb layer, shrub layer, spatial patterns

\section{Introduction}

Light is commonly viewed as the most important resource determining establishment, reproduction and growth of plants within forests and, not surprisingly, it is also the most heterogeneous in time and space (Pearcy 2007). The understory light environment is both cause and result of forest dynamics (Nicotra et al. 1999). Variations in light availability are expected to affect structure and composition of herb layer vegetation within tropical forests (Lima \& Gandolfi 2009). Nevertheless, only a few studies ever quantified the patchiness of forest light conditions
(Clark 1996; Nicotra et al. 1999; Valladares \& Guzmán 2006) or examined how spatial variation in light conditions relates to the spatial organization of herb layers in tropical forests (Montgomery 2004), especially in coastal systems (Souza \& Martins 2005).

The light environment is mainly determined by canopy structure, which directly affects growth and survival of seedlings and saplings (Kabakoff \& Chazdon 1996; Nicotra et al. 1999; Montgomery \& Chazdon 2001; Melo et al. 2007). This is because light availability has strong effects on the physiological processes of forest plants (Denslow et al. 1990). Spatial patchiness of light availability within

\footnotetext{
${ }^{1}$ Programa de Pós-Graduação em Ecologia de Ecossistemas, Laboratório de Ecologia Vegetal, Universidade Vila Velha, Rua Comissário José Dantas de Melo, s/n, Boa Vista, 29102-770, Vila Velha, ES, Brazil

${ }^{2}$ Laboratório de Botânica, Centro de Ciências Exatas, Naturais e da Saúde, Universidade Federal do Espírito Santo, Rua Alto Universitário, s/n, Guararema, 29500-000, Alegre, ES, Brazil

${ }^{3}$ Universidade Vila Velha, Rua Comissário José Dantas de Melo, s/n, Boa Vista, 29102-770, Vila Velha, ES, Brazil
} 
forests is mainly caused by canopy gaps due to treefall (Denslow et al. 1990), selective logging (Nicotra et al. 1999; Beaudet $\&$ Messier 2002) and crown architecture (Takeda \& Kawamura 2002; Kitajima et al. 2005; Pearcy et al. 2005). The role that canopy gaps play in forest regeneration is a central research topic (Pearcy 2007). Nevertheless, there is a multitude of other processes affecting the patterns of shrub layer vegetation within forests. These include plant-plant interactions (Ewel \& Hiremath 2005; Garbin et al. 2016), deciduousness of trees (Souza et al. 2014), soil heterogeneity (Tateno \& Takeda 2003; Townsend et al. 2008) and plant dispersal (Braz \& Mattos 2010), all of which may interact with light heterogeneity. Thus, even though light can have a strong filtering effect on the organization of understory vegetation, the spatial organization of plant communities is a result of many different processes. Because these competing hypotheses are not mutually exclusive (Uriarte et al. 2005), quantitative data are needed to understand the relative contribution of factors that determine spatial patterns of the shrub layer.

Regardless of the importance of variation in light availability in explaining plant growth and distribution patterns, few studies made use of spatially explicit analytical tools to measure heterogeneity in forests (but see Valladares \& Guzmán 2006). Most studies compared different vegetation types (e.g. Montgomery 2004) or estimated the effects of gap creation on regeneration patterns (e.g. Nicotra et al. 1999). Many replicates are required to reliably estimate spatially explicit patterns of canopy openness or light availability, which may explain the lack of studies in this regard. Using spatially explicit mapping approaches would allow the quantification of patch size and magnitude (contrast) of the light environment in tropical forests. Patch size (spatial autocorrelation) varies between 1 and 20 meters (Clark et al. 1996; Nicotra et al. 1999; Pearcy 2007) to about 50 meters (Yamada et al. 2014), or even 125 meters (Souza \& Martins 2005) when canopy openness is considered. However, the complex nature of the interplay between plant-plant interactions and spatial light heterogeneity in the understory of tropical forests has hardly been assessed.

Our study site, a coastal plain in Brazil (hereafter, restinga), has a marked zonation pattern in plant physiognomies from seashore to inland shaped by wind and sea level oscillations (Araujo \& Pereira 2004). Coastal systems represent a great challenge to plants that are constantly stressed by wind, salt, flooding and the threat of losing habitat due to sea level variation (Crawford 2008), requiring a continuous adjustment to changing climate conditions (Church et al. 2013). Although negative interactions can also occur among subordinate species (Garbin et al. 2016), positive interactions are an important structuring mechanism in restingas (Scarano 2002; Dias $\&$ Scarano 2007). Terrestrial bromeliads are an important component of these systems (Araujo 1992; Pereira et al. 2004), known for nursing the Clusia hilariana Schltdl. tree, the main nurse plant in the restingas (Correia et al. 2010) and for trapping palm seeds while negatively affecting palm seedlings (Brancalion et al. 2009).

These conflicting observations may be related to the strong effect of stress conditions on plant interactions (Bertness \& Hacker 1994; Callaway et al. 2002; Michalet et al. 2006; Brooker et al. 2007). The benefit from nurse plants may not change with increasing distance from seashore (Castanho \& Prado 2014). Moreover, distance from seashore did not affect the outcome of associations between different life forms, such as trees, herbs, climbers or shrubs (Castanho et al. 2012). Brancalion et al. (2009) found that terrestrial bromeliads were mainly present in open canopy areas, where they negatively affected palm seedlings. Knowledge on how terrestrial bromeliads organize in space in response to canopy cover with increasing distance from seashore (a proxy for stress conditions, sensu Castanho et al. 2012) and how they associate with other life forms can provide a better understanding of the interplay between plant associations and light environment in restinga forests. This has not yet been quantitatively tested under a spatially explicit approach.

We aimed to identify the relative importance of the understory light environment and terrestrial bromeliads in explaining the abundance of different life forms along a coastal forest gradient from seashore towards inland in southeast Brazil. Our objectives were twofold. First, we aimed to identify patterns of association among different life-forms (bromeliads, palms, woody plants, climbing plants, and herbs), and the role of space (in the form of patches), forest cover and distance from seashore in explaining such patterns. We hypothesized that forest cover and distance from seashore are the main structuring factors that determine the abundance of the various life forms. Second, we sought to understand how canopy cover and bromeliads relate to other plant life forms by quantifying patterns of spatial covariation among these components, hypothesizing that terrestrial bromeliads, by preferentially occupying canopy gaps, negatively affect the abundance of other life forms in space due to their spatially aggregated growth patterns.

\section{Materials and methods}

\section{Study site}

The study was conducted in the Paulo César Vinha State Park (1,574.85 ha) in the municipality of Guarapari (20 $33^{\prime}-20^{\circ} 38^{\prime} \mathrm{S}$ and $40^{\circ} 26^{\prime}-40^{\circ} 23^{\prime} \mathrm{W}$, sea level). The plant communities in the park are located on quaternary sandy coastal plains in southeast Brazil (Scarano 2002; Araujo \& Pereira 2004). There is a wide variety of vegetation types including forests, shrubs and herbaceous plant communities delimited by sharp boundaries as a result of 
Celio M. Lopes, Flora Misaki, Karina Santos,

Carlos A. P. Evangelista, Tatiana T. Carrijo and Mário L. Garbin

the geomorphological diversity caused by changes in sea level (Araujo \& Pereira 2004; Pimentel et al. 2007). The climate is characterized as Aw (Köppen), with an average annual temperature of $23.3^{\circ} \mathrm{C}$, annual average rainfall of $1,307 \mathrm{~mm}$ and annual relative humidity of $80 \%$ (Assis et al. 2004a). Our study was conducted in the non-flooded coastal plain forest formation (Assis et al. 2004a) on a spatial gradient (about 350 meters) between the inland limits of the beach vegetation and the open shrub $C$. hilariana Schltdl. vegetation (Araujo \& Pereira 2004; Thomazi et al. 2013). This restinga forest has a continuous canopy of about 8 meters height and a herb layer vegetation that varies in composition and includes bromeliads, Arecaceae, Piperaceae, and Rubiaceae (Assis et al. 2004b). These forests are termed dry forests, sandy forests, non-flooded forests, or simply restinga forests (Assis et al. 2004a; Thomazi \& Silva 2014). The most abundant plant families in these forests are Myrtaceae, Bromeliaceae, Orchidaceae, Sapotaceae, Lauraceae, and Rubiaceae (Assis et al. 2004a). Details on the study location are available in Figure S1 in supplementary material.

\section{Sampling and image acquisition}

Field work was conducted between December 2015 and January 2016. We established 15 transects parallel to seashore (oriented in azimuth angle of 30 degrees). Each transect was 50 $\mathrm{m}$ long and the distance between them was $25 \mathrm{~m}$. We installed 11 sampling units ( $1 \mathrm{mx} 1 \mathrm{~m}$ plots) at every $5 \mathrm{~m}$ interval in each transect, resulting in 165 plots (15 transects $x 11$ plots) within 1.75 hectares ( $350 \mathrm{~m} \times 50 \mathrm{~m}$ ). Details on the study plot and sampling scheme are available in Figure $S 2$ in supplementary material. In each sampling unit, we surveyed the vegetation and acquired hemispherical photographs. We sampled seven different life forms: woody plants (tree saplings), climbing plants (woody or herbaceous), cacti, herbaceous plants, palms, bromeliads, and pteridophytes. However, cacti and pteridophytes were removed from the analyses due to their very low abundance and frequency in the plots. Sampling was conducted using an adapted cover pin frame approach (Dias et al. 2005; Garbin et al. 2012): at every $0.5 \mathrm{~m}$ interval of the plot, a thin stick ( $0.8 \mathrm{~cm}$ diameter) was positioned vertically, and the identity and the number of times each life form touched the stick was recorded up to a height of $1.5 \mathrm{~m}$. The nine pin assessments were pooled to obtain a measure of life form abundance (number of times each life form touched the stick).

Light environment was assessed indirectly using hemispherical photographs (Jonckheere et al. 2004; Weiss et al. 2004; Chianucci \& Cutini 2012). We used a digital camera model (Canon 1200D, resolution of $5184 \times$ 3456, and 72 dpi), with a fish eye lens (180 degrees field of view, 4,5 mm; Sigma Corp. of America, Ronkonhoma, NY, EUA), resulting in circular images. The camera was mounted on a tripod of $1.7 \mathrm{~m}$ height. Images were obtained in summer (growing season) when leaves are at their maximum expansion (Pérez-
Harguindeguy et al. 2013). All photographs were taken before sunrise, just after sunset or under an evenly overcast sky to ensure optimal backlight conditions (Jelaska 2004).

\section{Data analysis}

We used ordination methods, partial redundancy analysis (pRDA), spatial filtering using Moran's eigenvector mapping (MEM; see Dray et al. 2006 and Griffith \& PeresNeto 2006), and Moran's I splines. The objectives were: 1) to describe the main patterns of variation in life form abundance, 2) to partition this variation into spatial components (linear, gradient from seashore, and MEMs) and 3) to quantify univariate and bivariate spatial patterns for the different life forms and forest cover. All analyses were carried out in the R environment ( $\mathrm{R}$ Development Core Team 2015): simple and constrained ordinations were run in the vegan package (Oksanen et al. 2015), MEMs were run in the PCNM package (Legendre et al. 2013), Moran's I spline univariate and cross-correlograms were run in the ncf package (Bjørnstad 2015).

Images were processed using CAN-EYE version 6.313 (2014, INRA, France, available at http://www6.paca.inra. $\mathrm{fr} /$ can-eye). The camera fish-eye system was calibrated using the method described in http://www.avignon.inra. $\mathrm{fr} / \mathrm{can}$ _eye to compute the optical center and the projection function (Weiss \& Baret 2014). For each single image, the cover fraction (fCover) was computed. A set of 11 images of each transect was used to derive plant area index (PAI, at three different zenith angles, 38, 53, and 68 degrees, which correspond to the LAI2000 rings 3, 4, and 5, see Weiss et al. 2004), the fraction of absorbed photosynthetically active radiation (fAPAR, modeled and measured for white and black sky), gap fraction and modeled fCover. We adopted the term PAI, instead of LAI (leaf area index) because some leaves may be behind trunks, branches, and stems. Therefore, we followed Weiss \& Baret (2014) in that CAN-EYE provide estimates of PAI, but not LAI. Thus, nine light environment variables were used in the analyses.

Relative abundances of life forms were calculated for each sampling unit by dividing the total number of touches of each life form by the total number of touches of all life forms, with the resulting matrix (L) of sampling units per life form abundance. Matrix $C$ comprised fCover per plot. A third matrix $(\mathrm{X})$ was constructed using the local spatial coordinates ( $x$ and $y$ ) of each sampling unit. Another set of matrices was built considering each transect as a sampling unit. Raw abundance data (number of touches) for plots within a transect were pooled. Light environment data was composed by the nine variables generated in CAN-EYE (matrix P). Abundance matrices were normalized prior to the analyses (see Legendre \& Gallagher 2001). Environmental data (C and P) were standardized (McGarigal et al. 2000). Then, matrix X was expanded into Moran's Eigenvector predictors with positive Moran's I (calculated Moran's I 
greater than expected Moran's I) (Legendre \& Legendre 2012), resulting in matrix M. The Moran's eigenvector mapping (MEM) approach (Griffith \& Peres-Neto 2006; Dray et al. 2012) allowed us to model the relationship between life forms and environment while ensuring independence among sampling units, and modeling of more complex spatial structures in a context of canonical methods (Borcard et al. 2011; Legendre \& Legendre 2012). Using this approach, spatial dependence is filtered out by detrending, but the information from these spatial structures can be exploited as they may reveal the presence of unmeasured processes (McIntire \& Fajardo 2009; Dray et al. 2012).

First, we ran a Principal Coordinates Analysis (Legendre \& Legendre 2012) on matrix L, using the Bray-Curtis dissimilarity on the raw relative abundances matrix, in order to reveal the main trends of variation of life form abundance in the forest understory. Second, a partial redundancy analysis (pRDA; Økland 2003) was run using matrix $\mathrm{L}$ as response and matrices $M, X$, and $C$ as explanatory variables. Thus, we considered the gradient from seashore to inland as an explanatory linear spatial structure, and the MEMs as the more complex (patchy) structures (see Borcard et al. 2011). A forward selection of variables was run on the explanatory matrices using the ordistep function of the package vegan. Thus, partial constrained ordination (pRDA) was used to partition the variation of life form abundance into three sources: fCover, MEMs, and the linear gradient from seashore. Third, a second pRDA was run using the transects as sampling units. The response matrix was composed by the pooled life form abundance in each plot within a transect after standardization by total (relative abundance) and normalization (Legendre \& Legendre 2012). Explanatory datasets were the linear distances from seashore of each transect, matrix $\mathrm{P}$, and the abundance of bromeliads. These were extracted from the raw abundance matrix, which comprised the remaining life forms. This pRDA determined the bromeliads as an external cause over the other life forms within the forest. In all partitioning procedures, we used the RsquareAdj function in vegan to obtain unbiased estimates of fractions (Peres-Neto et al. 2006; Borcard et al. 2011). Lastly, spatial univariate and cross-correlation functions were estimated between bromeliads, fCover and the other life forms using spline (cross) correlograms (Bjørnstad and Falck 2001). Correlograms were built at a distance of $115 \mathrm{~m}$, roughly one third of the maximum amplitude. Uncertainty for spline (cross) correlograms was estimated by bootstrapping $(10,000$ iterations) and used to construct $95 \%$ envelopes.

\section{Results}

\section{Patterns of variation in life form abundance}

The first axis of the PCoA analysis showed that where bromeliads were abundant, other life forms were less present (Fig. 1). Two bromeliad species were dominant: Vrisea procera

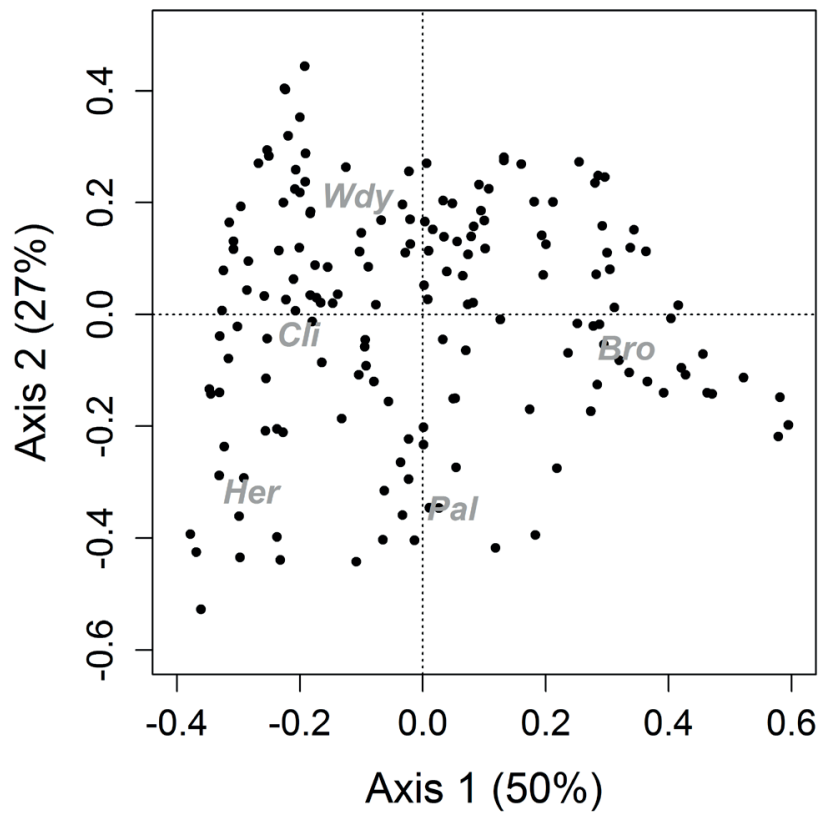

Figure 1. Principal coordinates analysis ( $\mathrm{PCOA}$ ) of different life forms (grey) in 165 plots in 1.75 hectares of a restinga forest understory. Bro, bromeliads; Pal, palms; Her, herbs; Cli, climbing plants; $W d y$, woody saplings. The analysis revealed a pattern of segregation between bromeliads and other life forms.

(Mart. ex Schult. \& Schult.f.) Wittm. and Ananas sagenaria (arruda) Schult. \& Schult.f.. The second axis distinguished the plots where herb species were more abundant than woody plants and bromeliads while abundance of climbers and palms was intermediate.

\section{Variation partitioning}

Canopy cover (fCover) was unrelated to the variation in life form abundance between plots (including bromeliads). The linear gradient from seashore explained only a small fraction (2\%) while MEMs explained the largest fraction $(17 \%)$ of variation in life form abundance (Fig. 2A). When transects were used as sampling units, bromeliads (32\%) and PAI (12\%) were the most important factors (Figs. $2 B, 3)$ in explaining patterns of life form abundance. The linear gradient had no significant relationship with life form abundance (with: $\mathrm{P}=0.81$, without: $\mathrm{P}=0.39$, bromeliads) and was not considered in the second partitioning procedure.

\section{Univariate and bivariate spatial patterns}

fCover (Fig. 4A), bromeliads (Fig. 4B) and herbs (Fig. 4C) were positively aggregated in space at scales between zero and 10 meters. Bromeliads were negatively associated in space with climbing plants (Fig. 4D), herbs (Fig. 4E) and woody plants (Fig. 4F). See Table S1 in supplementary material for light environment parameters of each transect derived using CAN-EYE. 
Variation shared among linear gradient, forest cover

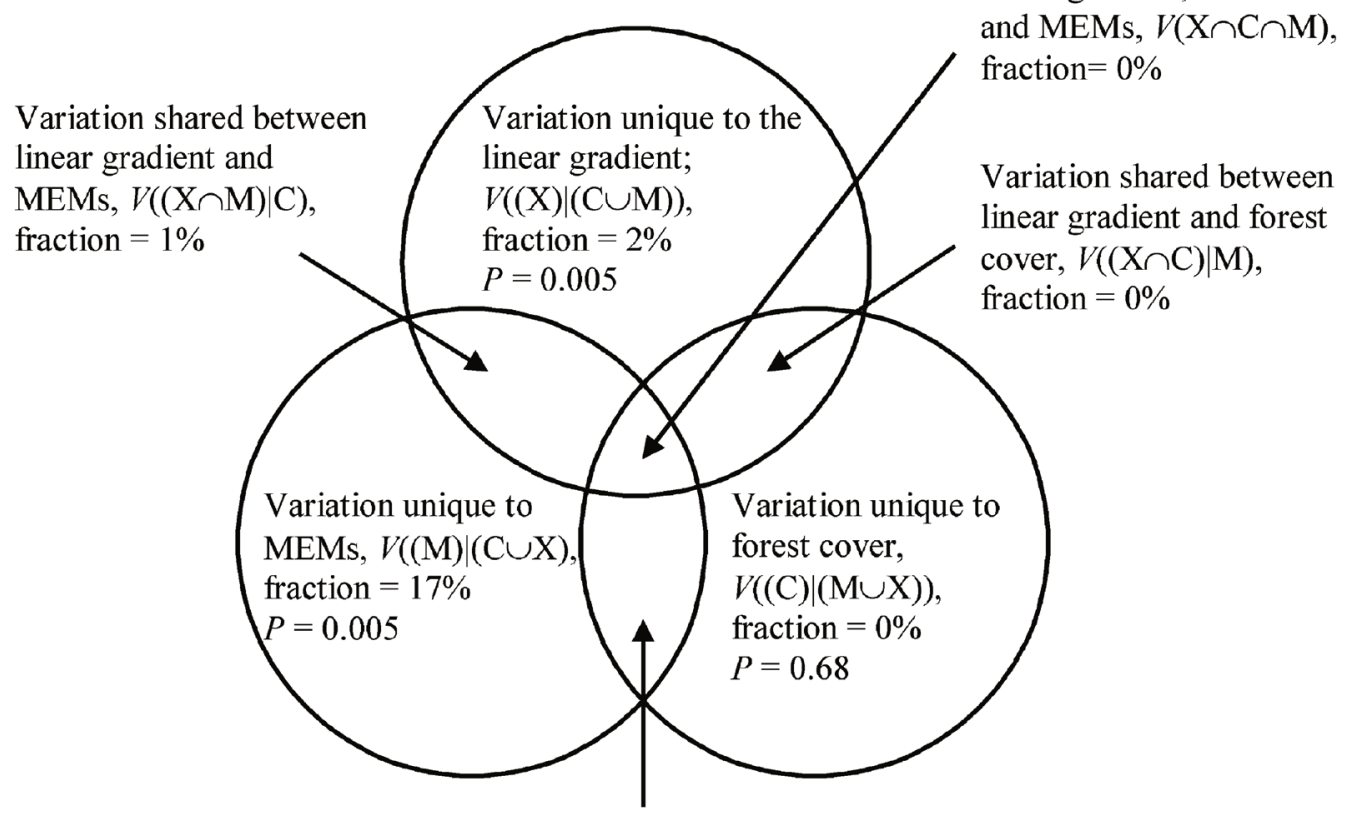

Variation shared between MEMs and forest cover, $V((\mathrm{M} \cap \mathrm{C}) \mid \mathrm{X})$, fraction $=-2 \%$

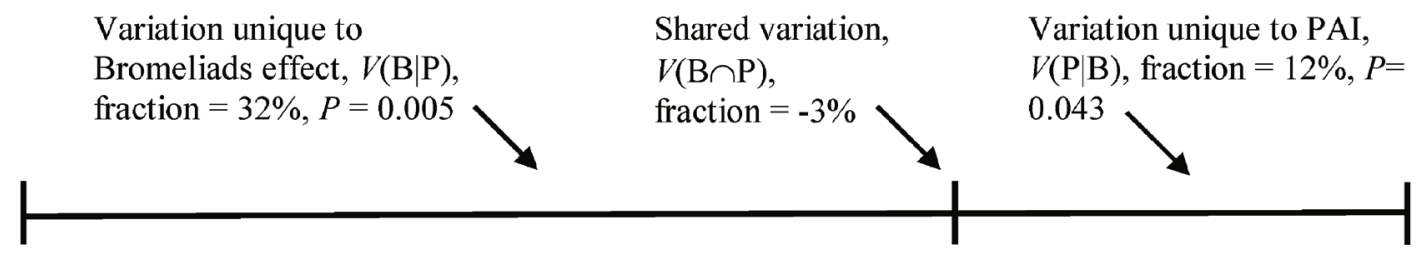

Figure 2. A) Venn diagram for the partitioning of life form abundance related to the linear gradient (X), fCover (C) and MEMs (M) as explanatory data sets. Total variation explained ( $\mathbf{X} \cup \mathbf{C} \cup \mathbf{M})$ was $18 \%(\mathrm{P}=0.005)$. B) Partition of the variation of life form abundance (after removing bromeliads) into two sources: bromeliads $(\mathbf{B})$ and light environment $(\mathbf{P})$. Total variation explained (BuP) was of 41 $\%(P=0.075) . \cup$, combined variation. $\cap$, shared variation. See Økland (2003) for a detailed formulation of the variation partitioning procedures. Negative fractions should be interpreted as zeroes (Legendre 2008). See text for details.

\section{Discussion}

We found that bromeliads have a stronger impact on structuring the shrub layer vegetation than canopy cover or distance from seashore in this tropical coastal forest. Despite the expected predominant role of light and stress tolerance in filtering understory vegetation, bromeliads were able to occupy the shadier parts of the forest (with high PAI) and, due to their aggregated spatial organization, other life forms were excluded from these sites. Bromeliads have been shown before to affect the presence and density of other plant groups within forests (Brokaw 1983; Wada 1993; Barberis et al. 2002; Barberis \& Lewis 2005). Nevertheless, in these studies, bromeliads had different effects on understory vegetation by either promoting regeneration or inhibiting other plant groups. In restingas and swamp forests, bromeliads are especially 


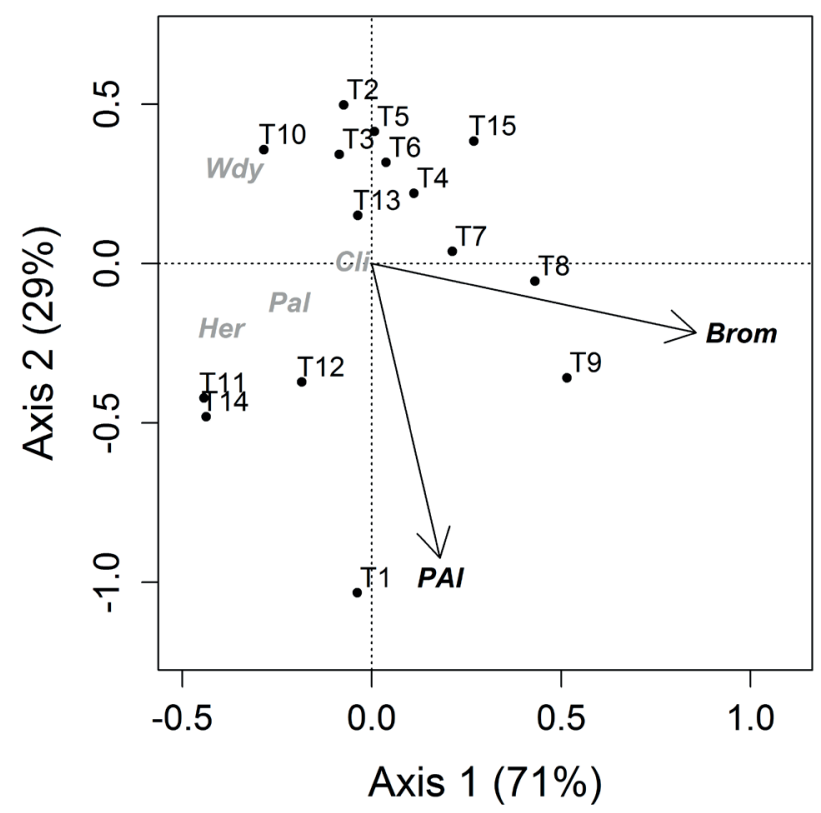

Figure 3. Axis 1 and 2 of a constrained ordination (RDA) of life form abundance constrained by light environment (PAI, plant area index) and bromeliads (Brom). Total variation explained by the model was $41 \%$. See Fig. 2B for fractions. T, transect; numbering from 1 to 15 depicts the position of the transect in relation to seashore, the higher the number, the closer the transect is to seashore.

known to nurse tree species (Scarano et al. 1998; Scarano 2006; Scarano 2009; Correia et al. 2010). When acting as a trap for seeds, they can competitively exclude palm seedlings (Brancalion et al. 2009). These authors found that bromeliads were negatively associated with shaded conditions and that conditions for palms were better where bromeliads were absent. In summary, our results suggest that bromeliads adjust to shaded conditions, establish dense colonies, and then inhibit woody, herbaceous and climbing plants, regardless of distance from seashore.

\section{The role of forest cover and distance from seashore}

In coastal systems, distance from seashore is a good proxy for abiotic stress (Castanho et al. 2012). In our study, the distance from seashore to the nearest transect was about 170 meters. It seems that the restinga forest and the beach vegetation (Araujo \& Pereira 2004) are capable to buffer the effects of wind and salt spray. Distance from seashore did not affect spatial associations and nurse effects in restingas (Castanho et al. 2012; Castanho \& Prado 2014). Moreover, in open shrub formations of the restinga, distance from seashore was not associated with floristic composition or structural parameters of the vegetation. In contrast, vegetation differed among plots parallel to the sea (Pimentel et al. 2007). Overall, our data suggest a limited role of abiotic stress associated with increasing proximity to seashore. We did not observe discernable effects of stress gradients on the organization of forest understory communities in this coastal system. Likewise, Castanho et al. (2012) found no evidence that spatial life form associations change with increasing distance from seashore. Our study showed that the findings for sand dunes (Castanho et al. 2012) and shrub vegetation (Pimentel et al. 2007) also apply to the forest formations in the restinga. Canopy cover, PAI, fAPAR and gap fraction were not related to distance from seashore, and the same was true for life form abundance of the shrub layer vegetation. Thus, it seems that the understory vegetation of these forests is buffered against the potentially harmful effects caused by the proximity to the seashore.

Understory plant species are affected by competition with canopy trees and lianas, and by low levels of light reaching the forest floor (Wright 2002). Low levels (less than $2-5 \%$ of the above canopy) and temporal heterogeneity of light reaching the floor (e.g. Canham et al. 1990) drive a wide variation in morphology and physiological plasticity of the understory species, directly affecting the observed patterns of diversity and species coexistence (Théry 2001; Valladares 2003). The vertical leaf orientation of bromeliads that would impair their capacity to harvest light, may be compensated by their high photosynthetic capacity and biomass allocation to leaf tissue (Valladares et al. 2002). Restinga bromeliads acclimate poorly to high levels of light under exposed conditions, while they seem to perform better and acclimate to more shaded conditions in forests (Duarte et al. 2002). In our study site, bromeliads appear to cope with high shade conditions (indicated by PAI) creating dense patches (as indicated by the large space fraction explained by MEMs), but the physiological mechanisms behind these patterns require further study. Moreover, the large fraction explained by MEMs indicated a highlyaggregated pattern of bromeliads unrelated to canopy cover. The patchy pattern of bromeliads and their dissociation in space with other plant life forms was evident in the spline and cross-correlogram outputs.

\section{Spatial patterns}

Terrestrial bromeliads seem to partition space with other groups of plant life forms. It is noteworthy that canopy cover and distance from seashore had no effect on the abundance of the different life forms studied. Understory light conditions are expected to affect shrub layer vegetation (Montgomery 2004). The patterns of spatial segregation between bromeliads and the other life forms, and the limited role of canopy cover and gradient stress in determining these patterns, point to an important role of competition for space and of dispersal limitation (see Barberis et al. 2014) in the spatial organization of the shrub layer of the restinga forest. Our results indicate that terrestrial bromeliads may have a 
Celio M. Lopes, Flora Misaki, Karina Santos,
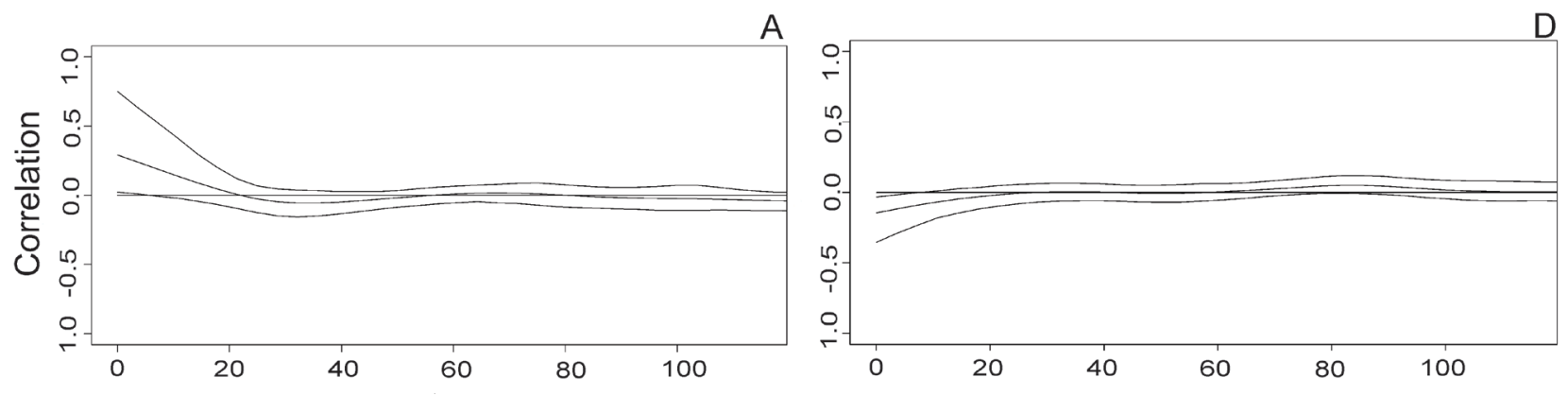

B
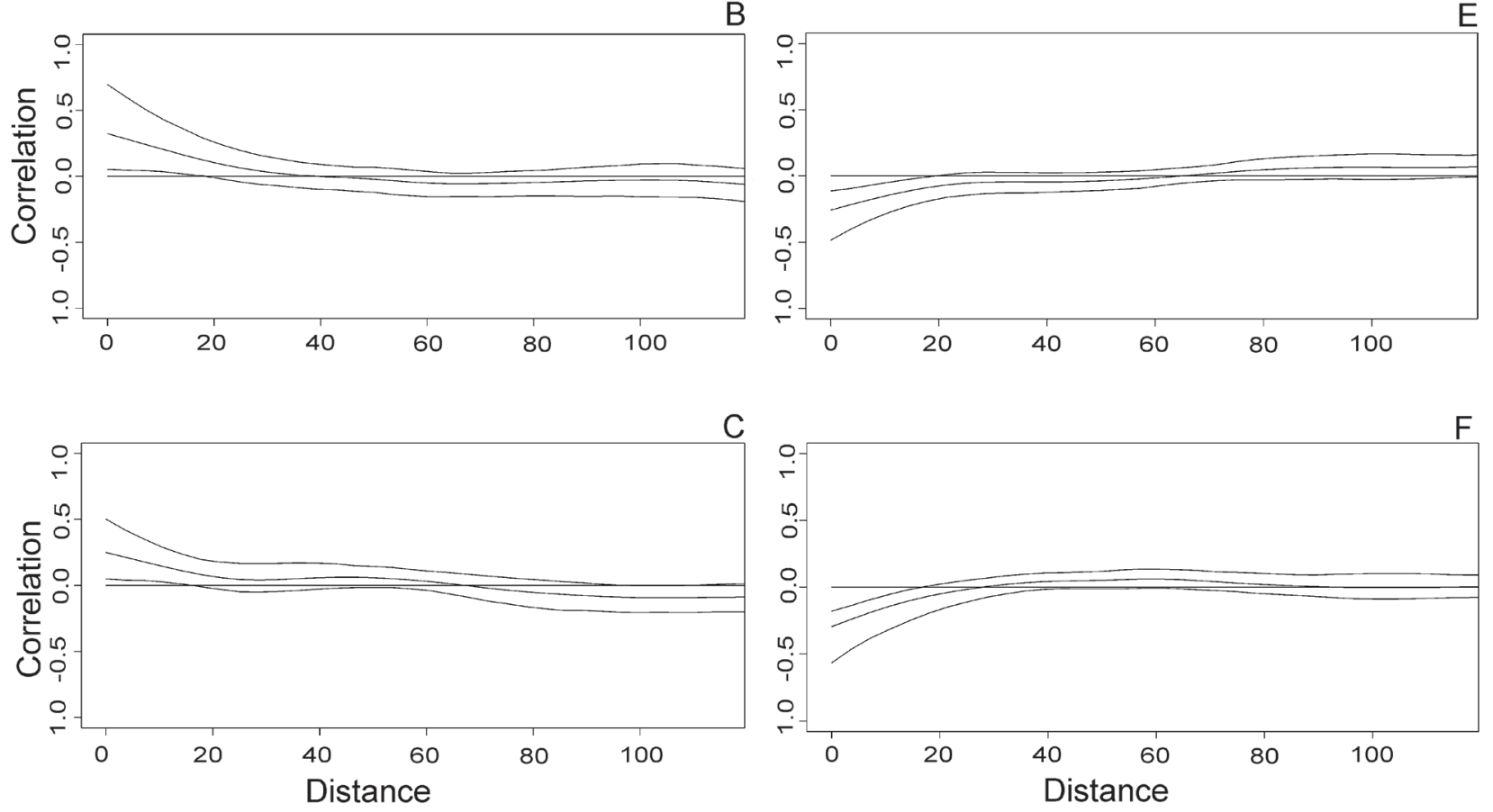

Figure 4. Univariate spline correlograms of A) fCover, B) bromeliads, and C) herbs in 1.75 ha of a restinga forest. Spline crosscorrelograms between bromeliads and: D) climbing plants, E) herbs, and F) woody plants. Upper and lower lines represent $95 \%$ envelopes. Envelopes below or above zero in splines depict negative and positive significant spatial structures, respectively. In univariate splines (A, B and C), there was a positive association at scales between zero and 10 meters as envelope is above the zero line at these scales. For the cross-correlograms (D, E and F), there was a negative association at scales between zero and 10 meters as envelope is below the zero line at these scales.

strong influence on structure and spatial organization of an understory plant community. Future studies should evaluate the physiological plasticity of bromeliads allowing them to cope with the different light environments of the restinga forest, and to measure patterns of tree seed germination and abundance of tree seedlings in sites with and without bromeliad colonies.

\section{Conclusions}

We showed that the assembly of the herb layer vegetation in this restinga forest is independent of canopy cover and distance from seashore. Importantly, terrestrial bromeliads tend to occupy the shadiest portions of the gradient (as indicated by PAI), and they seem to play a crucial role in determining the spatial organization of different life forms in this forest. Thus, these internal filters (sensu Violle et al. 2012) of the community (the local environmental conditions driven by PAI) and the density-dependent processes are more important than the external filters, such as distance from seashore (as a proxy for the stress gradient). The nonrandom co-occurrence patterns between terrestrial bromeliads and other life forms detected here (the negative cross-correlation spatial structure) provides evidence that biotic internal filters can be more important than external filters in the assembly of the herb layer vegetation in these forests. Future 


\section{The role of terrestrial bromeliads in determining the spatial organization \\ of plant life forms in a tropical coastal forest}

studies should assess the plasticity of bromeliads in coping with changes in light conditions, and address the question if different bromeliad species have different effects on other plant life forms, especially on seedlings and saplings of tree species regenerants.

\section{Acknowledgements}

We thank FAPES and Capes (Espírito Santo State Research Agency/Brazilian Research Agency), which granted fellowships to M.L. Garbin, F. Misaki, C. Lopes, and K. Santos. We thank FAPES for funding (grant $n^{\circ} 69329524 / 2015$ ). We thank K. Gregório-Martins for building the map and P.C. Cavatte and A.C.S. Araujo for helpful suggestions. We are also grateful to IEMA (Espírito Santo Environmental Agency) for collection licenses.

\section{References}

Araujo DSD. 1992. Vegetation types of sandy coastal plains of tropical Brazil: A first approximation. In: Seeliger U. (ed.) Coastal plant communities of Latin America. San Diego, Academic Press. p. 337-347.

Araujo DSD, Pereira MCA. 2004. Sandy coastal vegetation. In: Encyclopedia of Life Support Systems. Oxford, UNESCO, Eolss Publishers.

Assis AM, Pereira OJ, Thomaz LD. 2004a. Fitossociologia de uma floresta de restinga no Parque Estadual Paulo César Vinha, Setiba, município de Guarapari (ES). Revista Brasileira de Botânica 27: 349-361.

Assis AM, Thomaz LD, Pereira OJ. 2004b. Florística de um trecho de floresta de restinga no município de Guarapari, Espírito Santo, Brasil. Acta Botanica Brasilica 18: 191-201.

Barberis IM, Batista WB, Pire EF, Lewis JP, León RJC. 2002. Woody population distribution and environmental heterogeneity in a Chaco forest, Argentina. Journal of Vegetation Science 13: 607-614.

Barberis IM, Lewis JP. 2005. Heterogeneity of terrestrial bromeliad colonies and regeneration of Acacia praecox (Fabaceae) in a humid-subtropicalChaco forest, Argentina. Revista de Biologia Tropical 53: 377-385.

Barberis IM, Torres PS, Batista WB, Magra G, Galetti L, Lewis JP. 2014. Two bromeliad species with contrasting functional traits partition the understory space in a South American xerophytic forest: Correlative evidence of environmental control and limited dispersal. Plant Ecology 215: 143-153.

Beaudet M, Messier C. 2002. Variation in canopy openness and light transmission following selection cutting in northern hardwood stands: An assessment based on hemispherical photographs. Agricultural and Forest Meteorology 110: 217-228.

Bertness MD, Hacker SD. 1994. Physical stress and positive associations among marsh plants. The American Naturalist 144: 363.

Bjørnstad ON. 2015. ncf: Spatial Nonparametric Covariance Functions. R package version 1.1-6. https: //CRAN.R-project.org/package=ncf.

Bjørnstad ON, Falck W. 2001. Nonparametric spatial covariance functions: Estimation and Testing. Environmental Ecology Stat 8: 53-70.

Borcard D, Gillet F, Legendre P. 2011. Numerical Ecology with R. New York, Springer.

Brancalion PHS, Gabriel VDA, Gómez JM. 2009. Do terrestrial tank bromeliads in Brazil create safe sites for palm establishment or act as natural traps for its dispersed seeds? Biotropica 41: 3-6.

Braz MIG, Mattos EA. 2010. Seed dispersal phenology and germination characteristics of a drought-prone vegetation in southeastern Brazil. Biotropica 42: 327-335.

Brokaw N. 1983. Groundlayer dominance and apparent inhibition of tree regeneration by Aechmea magdalenae (Bromeliaceae) in a tropical forest. Tropical Ecology 24: 194-200.
Brooker RW, Maestre FT, Callaway RM, et al. 2007. Facilitation in plant communities: the past, the present, and the future. Journal of Ecology 96: 18-34.

Callaway RM, Brooker RW, Choler P, et al. 2002. Positive interactions among alpine plants increase with stress. Nature 417: 844-848.

Canham CD, Denslow JS, Platt WJ, Runkle JR, Spies TA, White PS. 1990. Light regimes beneath closed canopies and tree-fall gaps in temperate and tropical forests. Canadian Journal of Forest Research 20: 620-631.

Castanho CT, Oliveira AA, Prado PI. 2012. The importance of plant life form on spatial associations along a subtropical coastal dune gradient. Journal of Vegetation Science 23: 952-961.

Castanho CT, Prado PI. 2014. Benefit of shading by nurse plant does not change along a stress gradient in a coastal dune. PLoS One 9: e105082. doi: 10.1371/journal.pone.0105082.

Chianucci F, Cutini A. 2012. Digital hemispherical photography for estimating forest canopy properties: current controversies and opportunities. iForest - Biogeosciences and Forestry 5: 290-295.

Church JA, Clark PU, Cazenave A, et al. 2013. Sea level change. In: Stocker TF, Qin D, Plattner G-K, et al. (eds.) Climate Change 2013: The physical science basis. contribution of working group $i$ to the fifth assessment report of the intergovernmental panel on climate change. Cambridge, New York,Cambridge University Press. p. 1137-1216.

Clark DB. 1996. Landscape-scale evaluation of understory light and canopy structure : methods and application in a neotropical lowland rain forest . Canadian Journal of Forest Research 26: 747-757.

Clark DB, Clark DA, Rich PM, Weiss S, Oberbauer SF. 1996. Landscapescale evaluation of understory light and canopy structures: methods and application in a neotropical lowland rain forest. Canadian Journal of Forest Research 26: 747-757.

Correia C, Dias A, Scarano F. 2010. Plant-plant associations and population structure of four woody plant species in a patchy coastal vegetation of Southeastern Brazil. Brazilian Journal of Botany 33: 607-613.

Crawford RMM. 2008. Plants at the margin: Ecological limits and climate change. Cambridge, Cambridge University Press.

Denslow JS, Schultz JC, Vitousek PM, Strain BR. 1990. Growth responses of tropical shrubs to treefall gap environments. Ecology 71: 165-179.

Dias ATC, Scarano FR. 2007. Clusia as nurse plant. In: Lüttge U. (ed.) Clusia: A woody neotropical genus of remarkable plasticity and diversity. Berlin, Heidelberg, Springer Berlin Heidelberg. p. 55-71.

Dias ATC, Teixeira Zaluar HL, Ganade G, Scarano FR. 2005. Canopy composition influencing plant patch dynamics in a Brazilian sandy coastal plain. Journal of Tropical Ecology 21: 343-347.

Dray S, Legendre P, Peres-Neto PR. 2006. Spatial modelling: a comprehensive framework for principal coordinate analysis of neighbour matrices (PCNM). Ecological Modelling 196: 483-493.

Dray S, Pélissier R, Couteron P, et al. 2012. Community ecology in the age of multivariate multiscale spatial analysis. Ecological Monographs 82: $257-275$.

Duarte HM, Rocas G, Barreto SMB, et al. 2002. Acclimation or stress symptom? An integrated study of intraspecific variation in the clonal plant Aechmea bromeliifolia, a widespread CAM tank-bromeliad. Botanical Journal of the Linnean Society 140: 391-401.

Ewel JJ, Hiremath AJ. 2005. Plant-plant interactions in tropical forests. In: Burslem DFRP, Pinard MA, Hartley SE. (eds.) Biotic Interactions in the tropics: their role in the maintenance of species diversity. Cambridge, Cambridge University Press. p. 3-34.

Garbin ML, Carrijo TT, Sansevero JBB, Sánchez-Tapia A, Scarano FR. 2012. Subordinate, not dominant, woody species promote the diversity of climbing plants. Perspectives in Plant Ecology Evolution and Systematics 14: 257-265.

Garbin ML, Guidoni-Martins KG, Hollunder RK, Mariotte P, Scarano FR, Carrijo TT. 2016. Spatial segregation of subordinate species is not controlled by the dominant species in a tropical coastal plant community. Perspectives in Plant Ecology Evolution and Systematics 18: 23-32.

Griffith DA, Peres-Neto P. 2006. Spatial modeling in ecology: the flexibility of eigenfunction spatial analyses. Ecology 87: 2603-2613.

Jelaska SD. 2004. Analysis of canopy closure in the dinaric silver fir Beech Forests (Omphalodo fagetum) in Croatia using hemispherical photography. Hacquetia 3: 43-49. 
Jonckheere I, Fleck S, Nackaerts K, et al. 2004. Review of methods for in situ leaf area index determination Part I. Theories, sensors and hemispherical photography. Agricultural and Forest Meteorology 121: 19-35.

Kabakoff RP, Chazdon RL. 1996. Effects of canopy species dominance on understorey light availability in low-elevation secondary forest stands in Costa Rica. Journal of Tropical Ecology 12: 779-788.

Kitajima K, Mulkey SS, Wright SJ. 2005. Variation in crown light utilization characteristics among tropical canopy trees. Annals of Botany 95: 535-547.

Legendre P. 2008. Studying beta diversity: ecological variation partitioning by multiple regression and canonical analysis. Journal of Plant Ecology 1: 3-8.

Legendre P, Borcard D, Blanchet FG, Dray S. 2013. PCNM: MEM spatial eigenfunction and principal coordinate analyses [R package version 2.1-2/r109].

Legendre P, Gallagher E. 2001. Ecologically meaningful transformations for ordination of species data. Oecologia 129: 271-280.

Legendre P, Legendre L. 2012. Numerical Ecology, Third. Amsterdan, Elsevier.

Lima RAF, Gandolfi S. 2009. Structure of the herb stratum under different light regimes in the Submontane Atlantic Rain Forest. Brazilian Journal of Biology 69: 289-296.

McGarigal K, Cushman S, Stafford S. 2000. Multivariate Statistics for wildlife and ecology research. New York, Springer.

McIntire EJB, Fajardo A. 2009. Beyond description: the active and effective way to infer processes from spatial patterns. Ecology 90: 46-56.

Melo ACG, Miranda DLC, Durigan G. 2007. Cobertura de copas como indicador de desenvolvimento estrutural de reflorestamentos de restauração de matas ciliares no Médio Vale do Paranapanema, SP, Brasil. Árvore 31: 321-328.

Michalet R, Brooker RW, Cavieres LA, et al. 2006. Do biotic interactions shape both sides of the humped-back model of species richness in plant communities? Ecology Letters 9: 767-773.

Montgomery RA. 2004. Effects of understory foliage on patterns of light attenuation near the forest floor. Biotropica 36: 33-39.

Montgomery RA, Chazdon RL. 2001. Forest structure, canopy architecture, and light transmittance in tropical wet forests. Ecology 82: 2707-2718.

Nicotra AB, Chazdon RL, Iriarte SVB. 1999. Spatial Heterogeneity of Light and Woody Seedling Regeneration in Tropical Wet Forests. Ecology 80: 1908-1926.

$\varnothing \mathrm{kland}$ RH. 2003. Partitioning the variation in a plot-by-species data matrix that is related to $n$ sets of explanatory variables. Journal of Vegetation Science 14: 693-700.

Oksanen J, Blanchet FG, Kindt R, et al. 2015. Vegan: community ecology package. R package version 2.3-2. http: //CRAN.R-project.org/ package=vegan. 15 Jul. 2016.

Pearcy RW. 2007. Responses of Plants to Heterogeneous Light Environments. In: Pugnaire FI, Valladares F. (eds.) Functional Plant Ecology, 2nd. edn. Boca Raton, CRC Press. p. 724.

Pearcy RW, Muraoka H, Valladares F. 2005. Crown architecture in sun and shade environments: assessing function and trade-offs with a three-dimensional simulation model. New Phytologist 166: 791-800.

Pereira MCA, Cordeiro SZ, Araujo DSD. 2004. Estrutura do estrato herbáceo na formação aberta de Clusia do Parque Nacional da Restinga de Jurubatiba, RJ, Brasil. Acta Botanica Brasilica 18: 677-687.

Peres-Neto PR, Legendre P, Dray S, Borcard D, et al. 2006. Variation partitioning of species data matrices: estimation and comparison of fractions. Ecology 87: 2614-2625.

Pérez-Harguindeguy N, Díaz S, Garnier E, et al. 2013. New handbook for standardised measurement of plant functional traits worldwide. Australian Journal of Botany 61: 167.

Pimentel MCP, Barros MJ, Cirne P, et al. 2007. Spatial variation in the structure and floristic composition of "restinga" vegetation in southeastern Brazil. Revista Brasileira Botânica 30: 543-551.

R Development Core Team. 2015. A language and environment for statistical computing R Foundation for Statistical Computing, Vienna, Austria. URL http: //www.R-project.org/. 15 Jul. 2016.

Scarano FR. 2002. Structure, function and floristic relationships of plant communities in stressful habitats marginal to the Brazilian Atlantic rainforest. Annals of Botany 90: 517-524.

Scarano FR. 2006. Plant community structure and function in a swamp forest within the Atlantic rain forest complex: a synthesis. Rodriguésia 57: 491-502.

Scarano FR. 2009. Plant communities at the periphery of the Atlantic rain forest: Rare-species bias and its risks for conservation. Biology Conservation 142: 1201-1208.

Scarano FR, Rios RI, Esteves FA. 1998. Tree species richness, diversity and flooding regime: case studies of recuperation after anthropic impact in Brazilian flood-prone forests. International Journal of Ecology and Environmental Sciences 24: 223-235.

Souza AF, Martins FR. 2005. Spatial variation and dynamics of flooding, canopy openness, and structure in a neotropical swamp forest. Plant Ecology 180: 161-173.

Souza FFM, Gandolfi S, Rodrigues RRR. 2014. Deciduousness influences the understory community in a semideciduous tropical. Biotropica 46: 512-515.

Takeda H, Kawamura K. 2002. Light environment and crown architecture of two temperate Vaccinium species: Inherent growth rules versus degree of plasticity in light response. Canadian Journal of Botany 80: 1063-1077.

Tateno R, Takeda H. 2003. Forest structure and tree species distribution in relation to topography-mediated heterogeneity of soil nitrogen and light at the forest floor. Ecology Research 18: 559-571.

Théry M. 2001. Forest light and its influence on habitat selection. Plant Ecology 153: 251-261.

Thomazi R, Rocha R, Oliveira M, Bruno AS, Silva AG. 2013. Um panorama da vegetação das restingas do Espírito Santo no contexto do litoral brasileiro. Natureza On Line 11: 1-6.

Thomazi RD, Silva AG. 2014. Florística, diversidade e estrutura horizontal e vertical de uma área de vegetação arbstiva aberta numa planície arenosa costeira do Espírito Santo , sudeste do Brasil. Natureza On Line 12: 10-18.

Townsend AR, Asner GP, Cleveland CC. 2008. The biogeochemical heterogeneity of tropical forests. Trends in Ecology \& Evolution 23: 424-431.

Uriarte M, Hubbell SP, John R, Condit R, Canham CD. 2005. Neighbourhood effects on sapling growth and survival in a neotropical forest and the ecological-equivalence hypothesis. In: Burslem DFRP, Pinard MA, Hartley SE. (eds.) Biotic interactions in the tropics: Their role in the maintenance of species diversity. Cambridge, Cambridge University Press. p. 89-106.

Valladares F. 2003 Light heterogeneity and plants: from ecophysiology to species coexistence and biodiversity. In: Esser K, Lüttge U, Beyschlag W, Hellwig F. (eds.) Progress in botany: genetics physiology systematics ecology. Berlin, Heidelberg, Springer. p. 439-471.

Valladares F, Guzmán B. 2006. Canopy structure and spatial heterogeneity of understory light in an abandoned Holm oak woodland. Annals of Forest Science 63: 749-761.

Valladares F, Skillman JB, Pearcy RW. 2002. Convergence in light capture efficiencies among tropical forest understory plants with contrasting crown architectures: A case of morphological compensation. American Journal of Botany 89: 1275-1284.

Violle C, Enquist BJ, McGill BJ, et al. 2012. The return of the variance: Intraspecific variability in community ecology. Trends in Ecology \& Evolution 27: 244-252.

Wada N. 1993. Dwarf bamboos affect the regeneration of zoochorous trees by providing habitats to acorn-feeding rodents. Oecologia 94: 403-407.

Weiss M, Baret F. 2014. CAN-EYE V6.313 User Manual. https: //www6. paca.inra.fr/can-eye/

Weiss M, Baret F, Smith GJ, Jonckheere I, Coppin P. 2004. Review of methods for in situ leaf area index (LAI) determination Part II. Estimation of LAI, errors and sampling. Agricultural and Forest Meteorology 121: 37-53.

Wright SJ. 2002. Plant diversity in tropical forests: a review of mechanisms of species coexistence. Oecologia 130: 1-14.

Yamada T, Yoshioka A, Hashim M, Liang N, Okuda T. 2014. Spatial and temporal variations in the light environment in a primary and selectively logged forest long after logging in Peninsular Malaysia. Trees - Structure and Function 28: 1355-1365. 